\title{
USING SOME HONEYBEE PRODUCTS FOR CONTROLLING THE MICROBLAL CONTAMINATION OF DATE PALM TISSUE CULTURE STAGE
}

\author{
(Received : 13.3. 2014) \\ By \\ M.A. Abd El-Baky, A. A. Taha ${ }^{*}$ and N. A. Ghazala ${ }^{*}$ \\ Central Laboratory of Date Palm Research and Development - 'Beekeeping Research Department, \\ Plant Protection Research Institute, Agricultural Research Center, Giza, Egypt.
}

\begin{abstract}
This study was planned to investigate the antimicrobial properties of some honeybee products (propolis and bee venom) on bacterial and fungal contamination during the date palm tissue culture (Multiplication stage). Five varieties of date palm were used for this investigation (Sukery, Barhee, Rezeaz, Sakaey and Maghool). Penicillium sp. Aspergillus niger, Bacillus sp. and Pseudomonas sp. were isolated from Phoenix dactylifera cv. cultured in vitro in the multiplication and rooting stages. In addition, five dilutions of either bee venom or propolis $(1,2,3,4$ and $5 \mathrm{mg} / \mathrm{l})$ were used to control the fungal and bacterial contamination during the date palm tissue culture stage of the five varieties. Contaminated explants were cultured on bee venom or propolis containing media for one subculture (4 weeks). For bee venom, the results recorded that insignificant differences were observed between the control and each of the concentrations 1 and $2 \mathrm{mg} / \mathrm{l}$ for Sukery variety in contaminated jars. Meanwhile, the concentration $4 \mathrm{mg} / \mathrm{l}$ was significantly different than either the concentrations $1,2,3$ $\mathrm{mg} / \mathrm{l}$ or the control. On the other hand, for Barhee variety the concentration $5 \mathrm{mg} / \mathrm{l}$ resulted in more significantly survival and less contamination than the control and the other tested concentrations. There were no significant differences among Sukery, Barhee and Rezeaz for the concentrations 1, 2 and $3 \mathrm{mg} / \mathrm{l}$. The same difference was observed for Sakaey and Maghool varieties in concentrations 3, 4 and $5 \mathrm{mg} / \mathrm{l}$. For propolis, it was obvious that the concentration $4 \mathrm{mg} / \mathrm{l}$ was the highest significantly survival rate in Maghool variety. Insignificant difference in contamination for concentrations 1, 2, 3 and $4 \mathrm{mg} / \mathrm{l}$ of ethanol extract of propolis (EEP) for variety Sukery was observed. In addition, Maghool variety showed more significant survival and less contamination than the other varieties for concentrations 1,2 and $4 \mathrm{mg} / \mathrm{l}$.
\end{abstract}

Key words: bacteria, bee venom, date palm, disease-resistance, fungi, honeybee products, in vitroselection, propolis.

\section{INTRODUCTION}

The date palm, Phoenix dactylifera L. (Family: Palmaceae), is a monocotyledonous, dioecious and has long been one of the most important plants of arid, desert areas of northern Africa, the Middle East and southern Asia. Appropriately it is called "the palm of life". For over 5000 years, it has provided food, ornament and material for shelter, fiber, and fuel in a harsh environment where relatively few other plants are able to grow (Dowson, 1982; Zaid, 1999; Badawy et al., 2005). Humans have since spread the date palm far beyond its historical range, taking it to nearly all regions of the world where it can be grown. Even in more humid tropical and subtropical areas unsuitable for fruit production, the date palm is widely used as an ornamental palm (Hodel and Pittenger, 2003). Problems of breeding and propagation of date palm arise from the fact that the tree has a long life cycle (Ammar and Badeis, 1983), and that the number of off-shoots produced by the mother tree is limited to a certain period in the life of the tree (Barret, 1973). Also, the tree is dioecious and heterozygous (Abo El-Nil, 1986 and AlGhamdi, 1993). To meet the increasing demand for date palms, it is necessary to study the different factors affecting the productivity of the explants, with the aim of standardizing the tissue culture techniques that can be used for commercial production of date palms. The knowledge about diseases affecting this plant is 
somewhat limited. However, some serious diseases were reported in certain countries to cause great losses.

The use of chemical insecticides and pesticides is very common to control diseases and pests of date palm. These practices could become deadly health hazards to human health and that may also curtail their export market. Innovative techniques are needed to control diseases and pests. The influence of genotype has handicapped micro-propagation of different commercially valuable date palm varieties. This area needs serious attention by modifying the culture medium suited for several date palm cultivars. This type of work perhaps may require more empirical work in order to modify the composition of the culture medium (Mohan, 2012). To answer these questions, plenty of work is foreseen and in other words this area of research is 'virgin'. Therefore, the bee venom as a natural antimicrobial agent medically approved for human use was searched in this study to replace the antibiotics in tissue culture technology to overcome contamination and minimize the hazardous effect of chlorine at the recommended dose of concentration. That is because bee venom is more friendly than Clorox (sodium hypochlorite Na Hocl,4.5-5\%) with no residual effects and less cost (Abd-El Kareim et al., 2006; A-Reum, 2012). In addition, propolis is increasingly recognized by its antibacterial and antifungal properties. Propolis chemical composition is complex and varies according to its botanical and phytogeographical origin (Bankova and Marcucci, 2000; Bonvehi and Gutierrez, 2011).

This investigation was planned to select and develop date palm plants from selected resistant callus variants by using honeybee products (bee venom and propolis) as antimicrobial agents for fungi and bacterial diseases.

\section{MATERIALS AND METHODS}

The present study was carried out during 2013 at the Central Laboratory of Date Palm Research and Development, Agriculture Research Center, Giza. Egypt. The bee venom and propolis were collected from the apiary of Beekeeping Research Department, El-Kanater El-Khayreia, Qalyubia Governorate, Egypt.

\subsection{Bee venom preparation}

The honeybee venom was collected from bee hive using electric shook device and stored as powder ready to use. The bee venom was diluted in distilled water to different concentrations (El-
Shaarawy, 2008).

\subsection{Propolis (Bee glue) preparation}

Propolis was collected with propolis traps to minimize their contamination with foreign substances (Taha, 2006). Propolis samples were frozen at $-18{ }^{\circ} \mathrm{C}$ and milled in a refrigerator. Extracts were made by mixing $10 \mathrm{~g}$ crude propolis with $100 \mathrm{ml} \mathrm{96 \%} \mathrm{ethanol,} \mathrm{with}$ intermittent shaking at room temperature in dark for a week. The insoluble fraction was separated by filtration through Whatman No. 4 paper. The filtrate was named ethanol extract of propolis (EEP). The solubilized fraction was determined by weight difference. EEP at $10 \%(w / v)$ referred to crude propolis was used. Extracts were maintained in caramel flask in the dark at room temperature prior to antimicrobial testing (Tosi et al., 2007).

\subsection{The contamination}

Explants contaminated with fungi and bacteria were collected from the multiplication stage under investigation and then planted into potato- dextrose agar (PDA) plates and incubated at $25{ }^{\circ} \mathrm{C}$ for five days. The isolated fungi were identified using the description of Barnett and Hunter (1986). The isolated bacteria were identified using the description of Breed $e t$ al. (1974) and confirmed at the Bacterial Diseases Res. Dept., Agric. Res. Center, Giza.

\subsection{Preparing the media}

Four kinds of media were prepared, two for each stage (multiplication stage): Murashige and Skoog (MS) basal nutrient medium $+30 \mathrm{gm} \mathrm{l}^{-1}$ sucrose $+3 \mathrm{mg} \mathrm{l}^{-1}$ 2ip ( $\alpha \alpha$ Dimethyl amino purine) + venom. Media were autoclaved for 20 min at $121{ }^{\circ} \mathrm{C}$ in flasks. The flasks were allowed to cool down to $40{ }^{\circ} \mathrm{C}$ inside the laminar flow hood, then the different concentrations of bee venom were added using 0.02 micron syringe filter then flasks were shaken for distribution of bee venom dilutions $\left(1,2,3,4\right.$ and $\left.5 \mathrm{mg}^{-1}\right)$. Media were distributed in jars $(40 \mathrm{ml} / \mathrm{jar})$, then incubated for 4 days before using. The same method was done for the ethanol extract of propolis (EEP).

\subsection{Testing the plants}

Contaminated explants with bacteria were collected from the multiplication stage under investigation. Twenty jars were allocated for each concentration of venom and propolis from 1 to $5 \mathrm{mg} / \mathrm{l}$ in the multiplication stage of the palm tissue culture with 20 jars as control replanted on the same medium. All jars had a medium bacterial contamination with suitable healthy plants. The explants were first cleaned 
up in distilled sterilized water, then planted on the media. Explants were incubated in growth room at $26 \pm 2{ }^{\circ} \mathrm{C}$ in for $16 \mathrm{~h}$ and illumination of 2000 lux (white flourcent lamps). Sub-culturing the explants was done every 5 weeks ( 5 jars on free venom medium and the rest on the tested medium) to determine the effect of bee venom on the contamination, the response and the growth of the explants. Data were recorded as survival $\%$ and statistically analyzed by ANOVA and tabulated.

\section{RESULTS AND DISCUSSION \\ 3.1. Effect of bee venom on the contamination of multiplication stage}

Data presented in Table (1) showed that the concentration $4 \mathrm{mg} / \mathrm{l}$ of bee venom gave the highest survival rate $(90 \%)$ for Maghool date palm cultivar. Meanwhile, the fifth concentration $(5 \mathrm{mg} / \mathrm{l})$ gave the highest survival rate $(95 \%)$ for the Sakaey cultivar. The same trend was observed, where the concentration $5 \mathrm{mg} / \mathrm{l}$ of bee venom gave the highest survival rate for Sukery, Rezeaz and Barhee date palm cultivars with 85 , 85 and $90 \%$,respectively.

On the other hand, the first concentration 1 $\mathrm{mg} / \mathrm{l}$ was the inferior among all tested concentrations in survival rate of all date palm varieties. It could be concluded that using aqueous soluble solution of bee venom with date palm tissue culture technique with an average of $5 \mathrm{mg} / \mathrm{l}$ gave the highest percentage of survival rate and the least contamination rate. The previous results of bee venom are in agreement with those of many authors (Boman et al., 1989; El-Gizawy, 2006; El- Shaarawy, 2008). They observed that some of the honeybee venom affected the growth of bacteria. Kaviani et al. (1995) found that high dilutions of bee venom become not effective on the growth of some kinds of bacteria. From the previous results, it can be demonstrated that, the best bee venom concentration to use in date palm tissue culture is $5 \mathrm{mg} / \mathrm{l}$ as it can control the bacterial or fungal contamination and does not affect the plant vigor.

\subsection{The effect of bee venom on the contamination}

Data in Table (2) showed that insignificant differences were observed between the control and each of the concentrations 1 and $2 \mathrm{mg} / \mathrm{l}$ for Sukery variety in contamination jars. Meanwhile, the concentration $4 \mathrm{mg} / \mathrm{l}$ was significantly different than both the concentrations 1, 2, $3 \mathrm{mg} / \mathrm{l}$ and the control. The same trend was observed for Rezeaz and Maghool cultivars as the concentrations 4 and 5 $\mathrm{mg} / \mathrm{l}$ were outstanding in the survival rate. But there were insignificant differences among the control and the concentrations 1 and $2 \mathrm{mg} / \mathrm{l}$. On the other hand, for Barhee cultivar, the concentration $5 \mathrm{mg} / \mathrm{l}$ resulted in more significantly survival and less contamination than the control and the other tested concentrations. There were insignificant differences among Sukery, Barhee and Rezeaz for concentrations 1,2 and $3 \mathrm{mg} / \mathrm{l}$. The same difference was observed for Sakaey and Maghool cultivars in concentrations 3,4 and 5 $\mathrm{mg} / \mathrm{l}$.

\subsection{The effect of bee glue (propolis) on the contamination}

Data presented in Table (3) showed that the concentration $4 \mathrm{mg} / \mathrm{l}$ of bee propolis gave the highest survival rate $(60 \%)$ for Majhool date palm cultivar. Meanwhile, the concentration 5 $\mathrm{mg} / \mathrm{L}$ gave the highest survival rate $(30 \%)$ for the Sakaey cultivar. On the other hand, the concentration $1 \mathrm{mg} / \mathrm{l}$ of bee propolis was the inferior of all the tested concentrations in survival rate of all the date palm varieties. It could be concluded that using aqueous soluble solution of bee propolis with tissue culture date palm technique with an average percentage 5 $\mathrm{mg} / \mathrm{l}$ gave the highest percentage of survival rate and the least contamination rate.

Table (4) presents the analysis of variance for contamination jars of tissue culture treated with EEP ethanol extract of propolis with different concentrations. Data revealed that the most significant difference for survival was observed for concentration $4 \mathrm{mg} / \mathrm{l}$ in Maghool variety. Insignificant differences in contamination for concentrations 1, 2, 3 and $4 \mathrm{mg} / \mathrm{l}$ of EEP for cultivar Sukery were observed. Also, the same results were noticed in cultivar Sakaey. It is surprising that the control has the least contamination compared to the other tested concentrations, but with no significant difference in Sukery and Barhee cultivars. It is obvious that greater inhibition needs higher concentrations for ethanol extract of propolis. Maghool cultivar showed significantly more survival rate and least contamination than the other cultivars for concentrations 1, 2 and $4 \mathrm{mg} / \mathrm{l}$.

Some studies have been conducted on the antimicrobial activity of propolis against foodborne bacteria (Temiz et al., 2011) or plantorigin fungi (La Torre et al., 1990; Özcan et al., 2004; Soylu et al., 2004 and 2008). Fungi are 
Table (1): The effect of honeybee venom on tissue culture contamination and survival of the date palm Phoenix dactylifera $\mathbf{L}$.

\begin{tabular}{|c|c|c|c|c|c|c|c|c|c|c|}
\hline \multirow{2}{*}{$\begin{array}{l}\text { Media } \\
\text { Concentration Variety }\end{array}$} & \multicolumn{2}{|c|}{$1 \mathrm{mg} / \mathrm{l}$} & \multicolumn{2}{|c|}{$2 \mathrm{mg} / \mathrm{l}$} & \multicolumn{2}{|c|}{$3 \mathrm{mg} / \mathrm{l}$} & \multicolumn{2}{|c|}{$4 \mathrm{mg} / \mathrm{l}$} & \multicolumn{2}{|c|}{$5 \mathrm{mg} / \mathrm{l}$} \\
\hline & Cont. & Surv. & Cont. & Surv. & Cont. & Surv. & Cont. & Surv. & Cont. & Surv. \\
\hline Sukery & 10 & 10 & 8 & 12 & 6 & 14 & 4 & 16 & 3 & 17 \\
\hline Barhee & 9 & 11 & 7 & 13 & 7 & 13 & 5 & 15 & 2 & 18 \\
\hline Rezeaz & 10 & 10 & 6 & 14 & 6 & 14 & 5 & 15 & 3 & 17 \\
\hline Sakaey & 7 & 13 & 4 & 16 & 2 & 18 & 2 & 18 & 1 & 19 \\
\hline Maghool & 5 & 15 & 3 & 17 & 3 & 17 & 2 & 18 & 2 & 18 \\
\hline
\end{tabular}

Average value of three replicates (No. of treated Jars), Cont.=contamination; Surv.=survival

Table (2): The analysis of variance for contamination jars of tissue culture treated with different concentrations of honeybee venom.

\begin{tabular}{|c|c|c|c|c|c|c|c|}
\hline Media & \multicolumn{6}{|c|}{ Concentrations } & \multirow{2}{*}{ LSD } \\
\hline Variety & Control & $1(\mathrm{mg} / \mathrm{l})$ & $2(\mathrm{mg} / \mathrm{l})$ & $3(\mathrm{mg} / \mathrm{l})$ & $4(\mathrm{mg} / \mathrm{l})$ & $5(\mathrm{mg} / \mathrm{l})$ & \\
\hline Sukery & $10^{\mathrm{a} 2} \pm 0.00$ & $10^{\mathrm{a} 1} \pm 0.58$ & $8^{\mathrm{ab} 1} \pm 1.15$ & $6^{\mathrm{bc} 1} \pm 1.15$ & $4^{\mathrm{dc} 1} \pm 0.58$ & $3^{\mathrm{d} 1} \pm 0.58$ & 2.41 \\
\hline Barhee & $12^{\mathrm{a} 1} \pm 0.58$ & $9^{b 12} \pm 1.15$ & $7^{\mathrm{bcl}} \pm 0.0$ & $7^{\mathrm{bc} 1} \pm 0.58$ & $5^{\mathrm{c} 1} \pm 0.58$ & $2^{\mathrm{d} 12} \pm 0.58$ & 2.05 \\
\hline Rezeaz & $7^{\mathrm{b} 3} \pm 0.58$ & $10^{\mathrm{a} 1} \pm 1.15$ & $6^{\mathrm{b} 12} \pm 1.15$ & $6^{\mathrm{b} 1} \pm 0.58$ & $5^{\mathrm{bc} 1} \pm 0.58$ & $3^{\mathrm{c} 1} \pm 0.58$ & 2.52 \\
\hline Sakaey & $6^{\mathrm{ab} 3} \pm 0.58$ & $7^{\mathrm{a} 23} \pm 0.58$ & $4^{\mathrm{bc} 23} \pm 1.15$ & $2^{\mathrm{cd} 2} \pm 0.58$ & $2^{\mathrm{cd} 2} \pm 0.58$ & $1^{\mathrm{d} 2} \pm 0.00$ & 2.05 \\
\hline Maghool & $4^{\mathrm{ab} 4} \pm 0.58$ & $5^{\mathrm{a} 3} \pm 0.00$ & $3^{\text {bc3 }} \pm 0.58$ & $3^{\mathrm{bc} 2} \pm 0.58$ & $2^{\mathrm{c} 2} \pm 0.00$ & $2^{\mathrm{c} 12} \pm 0.58$ & 1.45 \\
\hline LSD & 1.62 & 2.57 & 2.93 & 2.30 & 1.62 & 1.62 & \\
\hline
\end{tabular}

Table (3): The effect of Honeybee glue (propolis) on tissue culture contamination and survival of the date palm Phoenix dactylifera $\mathbf{L}$.

\begin{tabular}{|l|c|c|c|c|c|c|c|c|c|c|}
\hline \multirow{2}{*}{$\begin{array}{r}\text { Media } \\
\text { concentration Variety }\end{array}$} & \multicolumn{2}{|c|}{$\mathbf{1} \mathbf{~ m g / l}$} & \multicolumn{2}{c|}{$\mathbf{2 ~ m g / l}$} & \multicolumn{2}{c|}{$\mathbf{3 ~ m g / l}$} & \multicolumn{2}{c|}{$\mathbf{4}$ mg/l } & \multicolumn{2}{c|}{$\mathbf{5}$ mg/l } \\
\hline Sukery & Cont. & Surv. & Cont. & Surv. & Cont. & Surv. & Cont. & Surv. & Cont. & Surv. \\
\hline Barhee & 15 & 5 & 14 & 6 & 13 & 7 & 14 & 6 & 12 & 8 \\
\hline Rezeaz & 17 & 3 & 15 & 5 & 14 & 6 & 13 & 7 & 12 & 8 \\
\hline Sakaey & 17 & 3 & 14 & 6 & 14 & 6 & 13 & 7 & 13 & 7 \\
\hline Maghool & 18 & 2 & 16 & 4 & 15 & 5 & 15 & 5 & 14 & 6 \\
\hline
\end{tabular}

Average value of three replicates (No. of treated Jars), Cont.=contamination; Surv.=survival

Table (4): The analysis of variance for contamination jars of tissue culture treated with different concentrations of honeybee propolis.

\begin{tabular}{|c|c|c|c|c|c|c|c|}
\hline \multirow{2}{*}{$\begin{array}{c}\text { Media } \\
\text { Cultivar }\end{array}$} & \multicolumn{6}{|c|}{ Concentrations (mg/l) } & \multirow{2}{*}{ LSD } \\
\hline & Control & 1 (mg/l.) & $2(\mathrm{mg} / \mathrm{l})$. & 3 (mg/l.) & $4(\mathrm{mg} / \mathrm{l})$. & $5(\mathrm{mg} / \mathrm{l})$. & \\
\hline Sukery & $10^{\mathrm{c} 2} \pm 0.00$ & $15^{\mathrm{a} 2} \pm 1.15$ & $14^{\mathrm{ab} 1} \pm 0.58$ & $13^{\mathrm{ab} 12} \pm 1.15$ & $14^{\mathrm{ab} 1} \pm 1.15$ & $12^{\mathrm{bc} 12} \pm 0.00$ & 2.62 \\
\hline Barhee & $12^{\mathrm{b} 1} \pm 0.58$ & $17^{\mathrm{a} 12} \pm 1.15$ & $15^{\mathrm{abl}} \pm 0.58$ & $14^{\mathrm{ab} 1} \pm 2.31$ & $13^{\mathrm{b} 1} \pm 1.15$ & $12^{\mathrm{b} 12} \pm 0.58$ & 3.77 \\
\hline Rezeaz & $7^{c 3} \pm 0.58$ & $17^{\mathrm{a} 12} \pm 0.58$ & $14^{\mathrm{abl}} \pm 0.58$ & $14^{\mathrm{abl}} \pm 1.15$ & $13^{\mathrm{bl}} \pm 1.73$ & $13^{\mathrm{bl}} \pm 1.73$ & 3.63 \\
\hline Sakaey & $6^{b^{3}} \pm 0.58$ & $18^{\text {al }} \pm 0.58$ & $16^{\mathrm{al}} \pm 2.31$ & $15^{\mathrm{al}} \pm 1.15$ & $15^{\mathrm{al}} \pm 0.58$ & $14^{\mathrm{al}} \pm 2.31$ & 4.53 \\
\hline Maghool & $4^{\mathrm{c} 4} \pm 0.58$ & $11^{\mathrm{a} 3} \pm 0.58$ & $9^{\mathrm{ab} 2} \pm 1.73$ & $9^{\mathrm{ab} 2} \pm 0.58$ & $8^{\mathrm{b} 2} \pm 0.00$ & $8^{b 2} \pm 0.58$ & 2.62 \\
\hline LSD & 1.63 & 2.70 & 4.31 & 4.38 & 3.45 & 4.23 & \\
\hline
\end{tabular}

common molds related to food products and can cause health problems in humans because of their mycotoxin producing properties. The value of propolis as antimicrobial agent was related to different constituents of propolis (Bankova et al., 2000). In addition, the strong antimicrobial activity of propolis may be due to the presence of diverse phyto-chemical compounds, mainly flavonoides, confirming the traditional reputation of propolis as a powerful antibacterial agent.

El-Dessouki et al. (2013) tested the effect of 
propolis ethanol $70 \%$ extract on the growth of three bacterial species. They showed that increasing extract concentration, the zone of growth inhibition increased in the three tested bacterial species, and the medium concentration $(4 \mathrm{mg} / \mathrm{l})$ was intermediate. The bactericidal or bacteriostatic effects depend on the concentration of propolis extract, and are influenced by the extraction method (Obregon and Hernandez, 1990). These results indicated that the antimicrobial activity of EEP does not depend upon the concentration of particular flavonoides but on the synergistic effects of all phenolic compounds (Kosalic et al., 2003).

In conclusion, using honeybee products as antimicrobial agents in tissue culture technique needs more research to show the ideal dose and the best product.

\section{REFERENCES}

Abd-El Kareim A. H., Rashed M. F. and Sharabasy S.F. (2006). Impact of using some fungicides and antibiotics on controlling microbial contamination during all stages of date palm tissue culture protocol. J. Agric. Sci. Mansoura Univ., 31 (5):2805-2814.

Abo El-Nil M. M. (1986). The effect of amino acid on growth of date palm callus. $2^{\text {nd }}$ Symp. of Date Palm., King Faisal University, Al-Hassa, Saudi Arabia, pp. 5965.

Al-Ghamdi A. S. (1993). True-to-type date palm (Phoenix dactylifera L.) produce through tissue culture technique. Produce of planters in vitro. The third symposium on date palm in Saudi Arabia, pp. 57.

Ammar S. and Badeis A. A. B. (1983). Vegetative propagation of date palm (Phoenix dactylifera L.) by in vitro culture. Proceedings of the First Symposium on the Date palm in Saudi Arabia, 158-166.

A-Reum Yu. (2012). The antifungal activity of bee venom against deratophytes. The Korean Society for Applied Biological Chemistry, 55(1):7-11.

Badawy E. M., Habib Afaf M. A., El-Bana A. and Yosry Gehan M. (2005). Propagation of date palm (Phoenix dactylifera) plants by using tissue culture technique. Arab J. Biotech., 8 (2): 343-354.

Bankova V. and Marcucci M.C. (2000). Standardization of propolis: present status and perspectives. Bee World, 8 (4): 182188.
Bankova V., Marcucci M.C. and Castro S.L. (2000). Propolis: recent advances in chemistry and plant origin. Apidologie, 31 : 3-15.

Barnett H. L. and Hunter B. B. (1986). Illustrated genera of fungi. 4th Ed. New York, M. Nillan Publishing Co., 212 pp.

Barret M. C. (1973). Date breeding and improvement in North America. Fruit Var. J., 27: 50-55.

Boman H. G., Wade D., Boman L. A., Wahlin B. and Merrifield R. B. (1989). Antibacterial and antimalarial properties of peptides that are cecropin- melittin hybrids. FEBS-1106.

Bonvehi J. S. and Gutierrez A. L. (2011). The antimicrobial effects of propolis collected in different regions in the Basque country (Northern Spain). World J. Microbiol. Biotechnol., Doi 10. 1007/s 11274-0110932-y.

Breed R. S., Marfoy J. G. D. and Hichnas A. P. (1974). Bergy's manual of determinative bacteriology, Williams and Wikins co. Bultimore, MD.,USA.

Dowson V.H.W. (1982). Date production and protection. UN-FAO Plant Production and Protection Paper 35. Rome, Italy.

El-Dessouki S. A., El-Khawass K. A., Abou ElEnein H. T. and Tantawy H. A. (2013). Effect of honey bee propolis on certain human bacterial species (Bacillus subtilis, Escherichia coli and Klebsiella pneumonia). Annals of Agric. Sci., Moshtohor, 51 (2): 141-144.

El-Gizawy S. A. (2006). The inhibitory effect of honey bee venom against some different microorganisms. J. Agric. Sci. Mansoura Univ., 31(5): 3169-3177.

El-Shaarawy K. O. (2008). Studies on certain factors affecting the honeybee venom collection, some chemical and antibacterial properties. Ph.D. Thesis, Faculty of agriculture, Cairo University, 108 pp.

Hodel D. R. and Pittenger D. R. (2003). Date palm establishment. Palms, 47 (4): 191-200.

Kaviani B., Fhorbannia E., Al-Saadi D. and Saadi D. A. (1995). Collection and standardization of honey bee venom in Iran. Journal of Natural Toxins, 4(2): 139-146.

Kosalic I., Bakmaz M. and Pepeljnjak S. (2003). Analysis of propolis from the Continental and Adriatic regions of Croatia. Acta Pharm., 53: 275-285.

La Torre A., Imbroglini G. and Guccione M. 
(1990). Action of propolis based preparations against Botrytis cinerea Pers. of strawberry. First Observation Agric, 6: 169-177.

Mohan S. J. (2012). Date palm biotechnology: Current status and prospective- an overview. Emir. J. Food Agric., 24 (5): 386399.

Obregon F. A. M. and Hernandez R. N. (1990). Antimicrobial action of alcoholic extracts of propolis. Revista Cubana de Farmacia, 24 (1): 34-44.

Özcan M., Ünver A., Ceylan DA. and Yetiflir R. (2004). Inhibitory effect of pollen and propolis extracts. Nahrung, 48 (3): 188-194.

Soylu EM., Özdemir AE., Ertürk E. and Fiahinler N. (2004). Antifungal activity of propolis against Penicillium digitatum, causal agent of green mold of citrus fruits. Proceedings of the First European Conference of Apidology. 'EurBee', Udine, Italy; pp. 160.

Soylu EM., Özdemir AE., Ertürk E., Fiahinler N. and Soylu S. (2008). Chemical composition and antifungal activity of propolis against Penicillium digitatum. Asian J. Chem., 20: 4823-4830.

Taha A.A. (2006). Comparative studies on some secondary products in different honeybee races. Ph.D. Thesis, Fac. Agric., Mansoura Univ., 212pp.

Temiz A., Fiener A., Tüylü AÖ., Sorkun K. and Salih B. (2011). Antibacterial activity of bee propolis samples from different geographical regions of Turkey against two food borne pathogens, Salmonella enteritidis and Listeria monocytogenes. Turk J. Biol., 35 (4): 503-511.

Tosi E. A., Edmundo Re', Marta E. O. and Cazzoli A. F. (2007). Food preservative based on propolis: Bacteriostatic activity of propolis polyphenols and flavonoids upon Escherichia coli.Food Chemistry,1(11):1-5.

Zaid A. (Ed.). (1999). Date palm cultivation. United Nations FAO, Plant Production and Protection Paper. 156. Rome,Italy.

$$
\begin{aligned}
& \text { إستخدام بعض منتجات نحل العسل لمقاومة التلوث الميكروبى لمزارع أنسجة نخيل البلح } \\
& \text { محمد عبد الرسول عبد الباقىـ- عمرو أحمد طه" ـ نجلاء الأحمدى غزاله } \\
& \text { المعمل المركزى لبحوث وتطوير النخيل ـ *قسم بحوث النحل ـ معهد بحوث وقاية النباتات } \\
& \text { مركز البحوث الزر اعيةـ الجيزة ـ مصر. }
\end{aligned}
$$

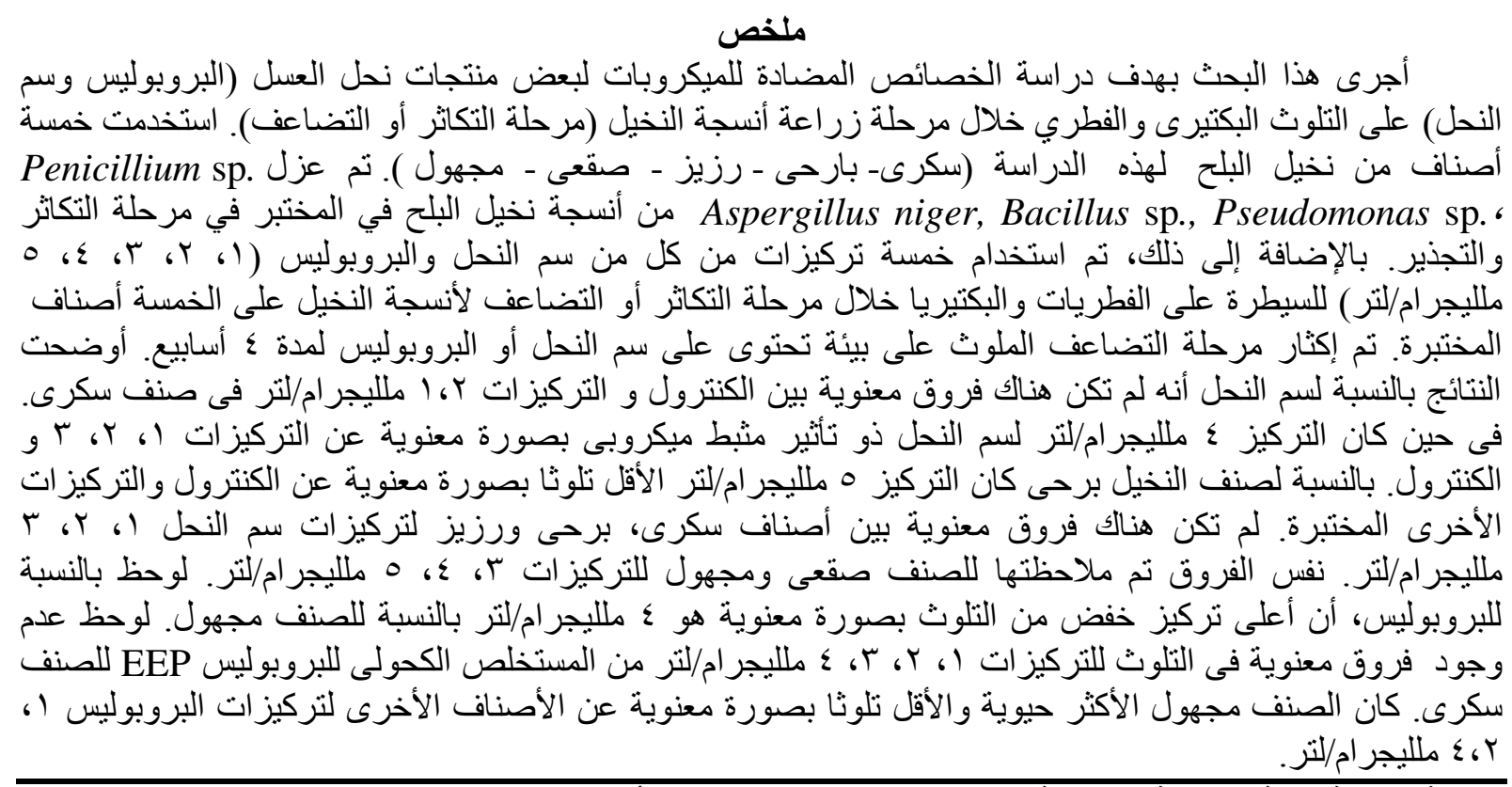

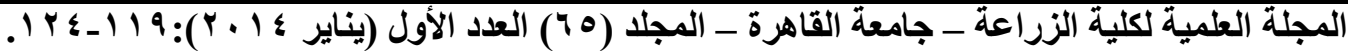

